Vol. 17 (2008): 121-126.

\title{
Research Note \\ Training dairy bull calves to stay within light-built electric fences
}

Paula Martiskainen

University of Kuopio, Department of Biosciences, PO Box 1627, FI-70211 Kuopio, Finland, e-mail: paula.martiskainen@uku.fi

Leena Tuomisto, Arto Huuskonen

MTT Agrifood Research Finland, Animal Production Research, FI-92400 Ruukki, Finland

Jaakko Mononen

University of Kuopio, Department of Biosciences, PO Box 1627, FI-70211 Kuopio, Finland

\begin{abstract}
Training cattle to avoid electric fences before turnout to grazing reduces the risk of the animals breaking out from their paddock. We investigated the time needed for dairy bull calves to learn to avoid a light-built electric fence. Nineteen dairy bull calves were trained to an electric fence in a training yard during seven days. The number of electric shocks the animals received from the training fence was recorded continuously. After the training period, the calves were turned to pasture. Nine of the animals were also grazed the following summer as yearlings, and observed before turnout in a smaller enclosure. The calves got more shocks from the fence during training hour 1 than during any of the following seven hours. The number of shocks the calves received from the fence also declined from training day 1 to 2 and from training day 3 to 4 . The results indicate that the dairy bull calves learned to avoid an electric fence quickly, even within an hour from release into the training yard. A simple training procedure was sufficient to ensure that the animals could be grazed in and would avoid a light-built electric fencing system as calves and, even after a winter-housing period, as bulls.
\end{abstract}

Key-words: cattle, electric fences, learning, grazing

\section{Introduction}

In Finland, most cows and heifers are housed indoors during winter and grazed during summer months.
Cow paddocks are usually enclosed with costeffective, light-built electric fences that are easily taken down or moved according to the prevailing demand. Dairy bulls, which comprise the majority of Finnish beef production, are traditionally reared 
Martiskainen, $P$. et al. Training dairy bull calves to stay within electric fences

indoors throughout the year. Often farmers are of the opinion that fencing bulls in would require much heavier, more expensive and laborious constructions than cows to prevent the animals from breaking out of their paddocks. However, in addition to being beneficial to the health and welfare of the animals (e.g. Haskell et al. 2006, Hernandez-Mendo et al. 2007), grazing enables the utilisation of the cheap pasture forage and, especially in beef production, could reduce the workload in animal management.

Training heifers and steers to electric fences before turnout reduces the risk of the animals escaping from their enclosure (McDonald et al. 1981), and this could also be assumed to apply to bulls. However, the necessary length of the training period is not known, and practical difficulties may limit the time available for training on farms.

Therefore, we aimed to investigate the time needed for dairy bull calves to learn to avoid an electric fence. The results and the practical experiences from grazing the animals as calves and yearlings were also used to provide recommendations on the methods of training and pasturing cattle in light-built electric fences.

\section{Material and methods}

The experimental procedures were evaluated and approved by the Animal Care and Use Committee of MTT Agrifood Research Finland.

Nineteen Finnish Ayrshire $(\mathrm{n}=15)$ and Holstein-Friesian $(n=4)$ bull calves were used in the experiment. The calves were purchased from local dairy farms at approximately two weeks of age. The animals were reared in group pens of 4-5 calves in a warm barn of the North Ostrobothnia Research Station of MTT Agrifood Research Finland. When the calves were on average 70 days old, they were moved to an uninsulated building and kept in one group pen $(8 \times 8 \mathrm{~m})$. One week later, an outdoor yard $(8 \times 8 \mathrm{~m}$, covered with a thick layer of woodchips) with a wooden plank fence was built adjacent to the pen. A training area was set up in the yard by building an electric fence approximately 70 $\mathrm{cm}$ inside the wooden fence. The fence consisted of two upper (height approx. $70 \mathrm{~cm}$ from the ground) and two lower (approx. $45 \mathrm{~cm}$ from the ground) stainless steel wires that were $5 \mathrm{~cm}$ apart, but connected together with plastic non-conductors. The fence was powered by a mains-operated energiser (Olli 450, Farmcomp Oy, Tuusula, Finland), which generated a maximum voltage of $5.6 \mathrm{kV}$.

The calves were released into the training yard on the first training day at 15:00 h. The training period lasted in total seven days, and the calves could move freely back and forth between the pen and the training yard. The training yard was videoed continuously using time-lapse video recording ( 3 frames / sec) from five black-and-white surveillance cameras. The number of electric shocks received by the calves was recorded continuously from the videotapes. Whether or not a calf got an electric shock was determined by their reaction after touching the fence. Behaviours used to denote an electric shock after touching the fence were e.g. flinching and backing up, hurriedly leaving the fence, vigorous head-shaking, standing still staring at the fence, or any combination of the aforementioned reactions. Only the cases where receipt of an electric shock was certain were recorded.

After the seven-day training period, the calves were turned to rotational grazing for four months in two groups of nine and ten animals. Pasture fences were constructed of fiberglass posts (weight 163 g) designed for temporary fencing, with two stainless steel wires at approximately the same heights as in the training fence, and were powered by the same energiser. Descriptive data on the behaviour of the calves at pasture was collected by direct observation for one hour following the turnout. The animals were housed in the uninsulated building for the following winter in groups of 4-5 animals, and nine of them were grazed again as bulls in the same fencing system the following summer. The bulls were observed directly in a small yard with a training electric fence for one hour before turnout, and the number of shocks received from the fence was counted. Whether the animals escaped from pasture was also observed throughout both of the grazing periods.

The number of electric shocks each calf re- 
Vol. 17 (2008): 121-126.

ceived from the training fence was counted for seven 24-hour periods ("Days", D) starting at 15:00 h. Only the data from the first four 24-hour periods (D1-D4) of access into the training yard were used in the statistical analysis, because data were lost for eight hours at the end of D5 due to a power failure. The first eight hours $(\mathrm{H}$; D1H1D1H8 from 15:00 to 23:00 h) of D1, after which the calves did not enter the yard again until 5:00 $\mathrm{h}$ the following morning, were analysed separately to examine the distribution of electric shocks on a shorter time-scale. The effect of training day or hour on the number of received electric shocks was analysed using linear mixed model procedure in SPSS 14.0 for Windows (SPSS Inc., Chicago, IL, USA). The model used in the analyses was

$\mathrm{Y}_{\mathrm{ij}}=\mu+\beta_{\mathrm{i}}+\varepsilon_{\mathrm{ij}}$

where $\mu$ is the overall mean, $\beta_{i}$ the fixed effect of training hour or day $i$ (for hour $i=1, \ldots, 8$ and for day $i=1, \ldots, 4)$ and $\varepsilon_{i j}$ is the error term for individual $j(1, \ldots, 19)$ from the training hour or day $i$. A Box-Cox transformation was applied to the data to achieve normal distribution of the residuals. Akaike's information criteria was used to select a heterogenous first-order autoregressive covariance structure for repeated measurements for the betweendays analysis and a first-order autoregressive covariance structure for the between-hours analysis. Bonferroni adjustment of the $p$-values was used in the pairwise comparisons. The results are presented as back-transformed estimated marginal means with 95\% confidence intervals $(95 \% \mathrm{CI})$. Due to the transformation, the CIs are asymmetrical.

\section{Results and discussion}

The number of electric shocks per animal $\mathrm{h}^{-1}$ declined rapidly from the initial peak at the time of release into the training yard (Fig. 1 and 2a), and remained at a rather constant level during the remaining training period (Fig. 1). The calves got more shocks $\left(F_{7,73}=\right.$ $4.4, p<0.001)$ from the training fence during $\mathrm{D} 1 \mathrm{H} 1$

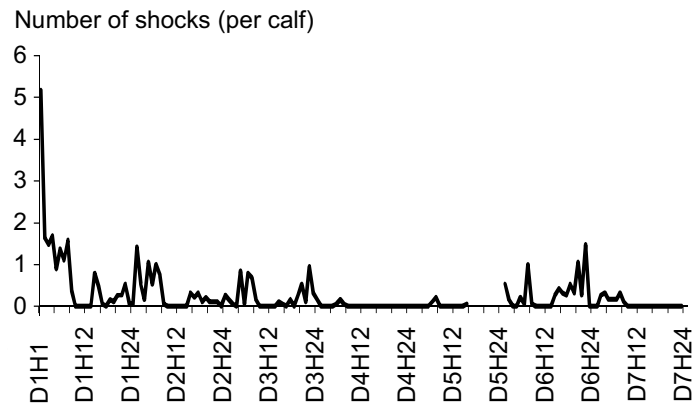

Time from the release into the training yard (day-hour)

Fig. 1. Distribution of electric shocks per calf $h^{-1}$ during the entire seven-day training period. The calves were let into the training yard at 15:00 $\mathrm{h}(15: 00-16: 00 \mathrm{~h}=\mathrm{D} 1 \mathrm{H} 1$ in the figure). The gap in the line indicates a power failure between hours D5H17 and D6H1, during which the data were lost.

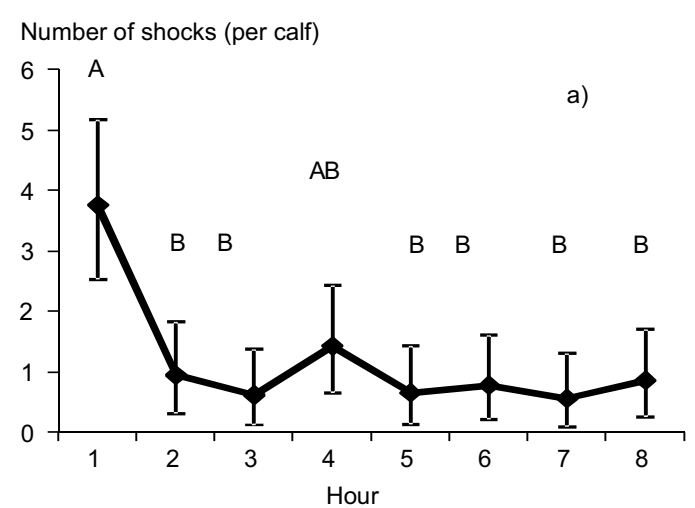

Number of shocks (per calf)

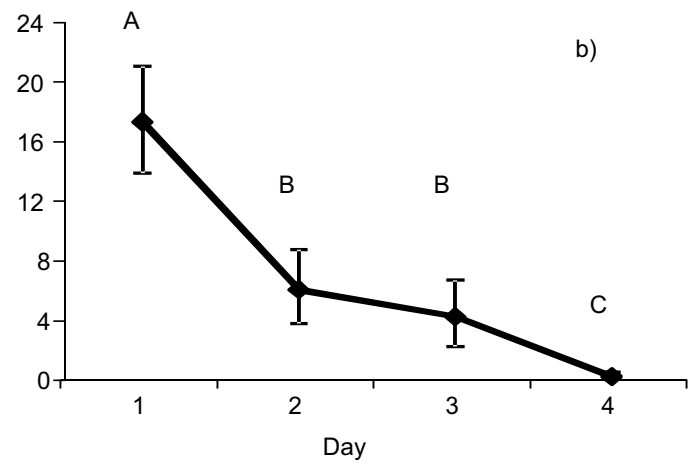

Fig. 2. Number of electric shocks per calf (back-transformed estimated marginal means and $95 \% \mathrm{CI}$ ) the calves received from the training fence a) during the hours 1-8 of the first training day, and b) during the training days $1-4$. The days or hours without a common superscript (ABC) differ $(p<0.05)$. 
Martiskainen, P. et al. Training dairy bull calves to stay within electric fences

than during the following seven hours, although the difference between D1H1 and D1H4 was not statistically significant (Fig. 2a). The number of shocks the calves received from the fence declined also $\left(F_{3,37}=76.8, p<0.001\right)$ from $\mathrm{D} 1$ to $\mathrm{D} 2$ and from D3 to D4 (Fig. 2b). The change was most notable between D1 and D2. Only one of the 19 calves never received a shock from the training fence after the first training day. In contrast, the calves were never seen to explore the pasture fences during the grazing season. The training yard itself did not offer enrichment to the animals, excluding the additional space and the training fence. This may have encouraged the calves to continue exploring the fence as a form of play or exploratory behaviour (see e.g. Phillips 2002), and may partially account for the wide range (on average 1.1 to 14.3 shocks per calf $\mathrm{d}^{-1}$ ) in the number of shocks received by the calves, as well as the fact that the number of shocks never reached a permanent zero level during the training period (see Fig. 1). Grazing may have served as sufficient enrichment and a channel for exploration for the calves at pasture, thus reducing the calves' interest in the pasture fences. The training fence was also constructed in a way that to receive a shock from the fence, an animal had to simultaneously touch both wires that were connected together with a plastic non-conductor, and this did not always take place. Consequently, some calves could rub their neck against the training fence wires for minutes without displaying signs of getting a shock. Obviously a training fence with a single wire or two separate wires could have been more efficient.

At the turnout to pasture, the first group of calves gambolled around the paddock area. The phenomenon is typical to cattle that are excited by e.g. transfer to novel environment (Hafez and Bouissou 1975). In the process two of the calves broke through a fence that separated adjacent paddocks. Subsequently a non-electrified white polytape (width $10 \mathrm{~cm}$ ) was added to the fence to run parallel to the electrified steel wires, and none of the animals in the second group moved to pasture made an attempt to break though. Instead, they stopped or turned before contacting the fence. During the grazing season, none of the calves escaped from the paddocks, even after power had been switched off from the fences for a few days near the end of the grazing period. Even though these observations are limited, it could be recommended that the pasture fences are constructed in a way that the animals are able to see the fence properly, especially at the turnout to pasture. This could prevent "accidental" escapes from pasture even in animals that have already learned to avoid electric fences.

McDonald et al. (1981) suggested in their study that training cattle makes them avoid electric fences long after the training has ended. When the initial shock from the electric fence is strong enough, the conditioned avoidance lasts for a longer period of time (badgers: Poole et al. 2004). Furthermore, steers learned to avoid a location more quickly on a high shock intensity $(5.8 \mathrm{kV})$ than on medium (5.6 $\mathrm{kV}$ ) or low (5.0 kV) intensities (Markus et al. 1998). Effects of the intensity of shock on the rate of learning were not examined in our study, but the voltage of at most $5.6 \mathrm{kV}$ seems to be sufficient to ensure learning of the avoidance reaction in calves. Nonetheless, it is reasonable to ensure that all animals have received a shock from the training fence before turnout to maximise the probability of electric fence avoidance (see McKillop and Wilson 1999 for reference in rabbits), even though learning avoidance by observing other animals being shocked has been suggested (McDonald et al. 1981).

Nine of the calves used in the experiment were turned out to graze a second time a year later as bulls. The bulls were observed in a small yard with a training electric fence for one hour before turnout. Each of the bulls investigated the electric fence and each received 1-2 electric shocks, but all were reluctant to touch the fence again. Therefore statistical analysis could not be applied to the results. None of the bulls broke out of their paddock while the fence was electrified during the grazing period. During a power failure, however, a few of the bulls broke the fence and escaped once. While the subject has been studied in wild rabbits (McKillop et al. 1993), there are no studies concerning the rate of extinction of conditioned electric fence avoidance in cattle.

Since electric fences per se provide cattle a mental barrier rather than a physical one, training should be carried out within a sturdier enclosure to ensure the animals have time to register the shock from the 
fence (see Moseby and Read 2006). Therefore, electric fence training is probably easiest to arrange in cattle as calves, when the animals are still relatively small. The experimental set-up in the current study was somewhat limited, because the calves were observed in the training period as a single group instead of two or three separate groups. Nevertheless, based on the present results, the calves learned to avoid the electric fence, and the conditioned avoidance lasted even beyond the winter-housing period. However, as bulls' behaviour is easily disturbed by environmental circumstances, such as presence of female cattle (see e.g. Hinch et al. 1982), the suitability of light-built electric fences for pasturing post-pubertal bulls should be considered carefully on each occasion.

In conclusion, dairy bull calves learned to avoid an electric fence quickly, even within an hour from release into a training yard. A simple training procedure was sufficient to ensure that the animals could be grazed in a light-built electric fencing system as calves and, even after a winter-housing period, as bulls. Dairy bull calves were used in the current experiment, but the results are likely to be applicable to other cattle, e.g. dairy heifers that are trained to electric fences or turned out to pasture for the first time.

Acknowledgements. This study was partially funded by the Employment and Economic Development Centre for Northern Ostrobothnia. The authors would like to thank personnel of the North Ostrobothnia research station of MTT Agrifood Research Finland for the care of the experimental animals and Mr. Vesa Kiviniemi for statistical help.

\section{References}

Hafez, E.S.E. \& Bouissou, M.F. 1975. The behaviour of cattle. In: Hafez, E.S.E. (ed.). The behaviour of domestic animals. 3rd ed. London, UK: Baillière Tindall. p. 203-245.

Haskell, M.J., Rennie, L.J., Bowell, V.A., Bell, M.J. \& Lawrence, A.B. 2006. Housing system, milk production, and zero-grazing effects on lameness and leg injury in dairy cows. Journal of Dairy Science 89: 4259-4266.

Hernandez-Mendo, O., von Keyserlingk, M.A.G., Veira, D.M. \& Weary, D.M. 2007. Effects of pasture on lameness in dairy cows. Journal of Dairy Science 90: 1209-1214.

Hinch, G.N., Thwaites, C.J. \& Lynch, J.J. 1982. A note on the grazing behaviour of young bulls and steers. Animal Production 35: 289-291.

Markus, S., Jensen, D., Bailey, D.W. \& Price, M. 1998. Effect of location and intensity of electrical shock on cattle movements. Journal of Animal Science 76, Suppl. 1: 97.

McDonald, C.L., Beilharz, R.G. \& McCutchan, J.C. 1981. Training cattle to control by electric fences. Applied Animal Ethology 7: 113-121.

McKillop, I.G. \& Wilson, C.J. 1999. The behaviour of freeliving European wild rabbits at electric fences. Crop Protection 18: 193-197.

McKillop, I.G., Ginella, S.G.V., Wilson, C.J., Hanlon, A.J. \& Pugh, B.D. 1993. The effects of power failure on the behaviour of European wild rabbits at electric fences. Applied Animal Behaviour Science 35: 277-290.

Moseby, K.E. \& Read, J.L. 2006. The efficacy of feral cat, fox and rabbit exclusion fence designs for threatened species protection. Biological Conservation 127: 429-437.

Phillips, C.J.C. 2002. Cattle behaviour and welfare. 2nd ed. Oxford, UK: Blackwell Science. 264 p.

Poole, D.W., Western, G. \& McKillop, I.G. 2004. The effects of fence voltage and the type of conducting wire on the efficacy of an electric fence to exclude badgers (Meles meles). Crop Protection 23: 27-33. 
Martiskainen, P. et al. Training dairy bull calves to stay within electric fences

\title{
SELOSTUS
}

\section{Sonnivasikoiden opettaminen pysymään kevytrakenteisissa sähköpaimenaitauksissa}

\author{
Paula Martiskainen, Leena Tuomisto, Arto Huuskonen, Jaakko Mononen \\ Kuopion yliopisto, Biotieteiden laitos, ja MTT Kotieläintuotannon tutkimus
}

\begin{abstract}
Maitotiloilla laitumien aitaamiseen käytetään yleensä kustannuksiltaan edullisia kevyitä sähköpaimenaitoja, jotka eivät kuitenkaan pysäytä eläimiä, elleivät ne ole oppineet kunnioittamaan aitoja laidunalueen rajoina. Tutkimuksemme tarkoituksena oli selvittää, kuinka nopeasti maitorotuiset sonnivasikat oppivat kunnioittamaan sähköpaimenaitaa ja kuinka niiden laiduntaminen onnistuu yksinkertaista aitausjärjestelyä käyttäen. Tutkimuksessa 19 maitorotuista sonnivasikkaa opetettiin varomaan sähköaitaa harjoitteluaitauksessa seitsemän päivän ajan, ja vasikoiden saamat sähköiskut laskettiin. Harjoittelujakson jälkeen eläimiä laidunnettiin sähköpaimenaitauksissa sekä vasikoina että yli vuoden ikäisinä sonneina. Vasikat
\end{abstract}

saivat ensimmäisen harjoittelutunnin aikana enemmän sähköiskuja ( $p<0,001$, lineaarinen sekamalli) kuin sitä seuraavina seitsemänä tuntina. Vasikoiden saamien sähköiskujen määrä väheni $(p<0,001)$ myös harjoituspäivien 1 ja 2 sekä 3 ja 4 välillä. Vasikoiden saamien sähköiskujen lukumäärien muutosten perusteella vasikat oppivat varomaan harjoitteluaitauksessa ollutta sähköaitaa jo yhden vuorokauden tai jossain määrin jopa ensimmäisen harjoittelutunnin aikana. Eläimet osasivat varoa yksinkertaisia sähköpaimenaitoja ja niitä voitiin laiduntaa ongelmitta sekä vasikoina että sonneina. Tuloksien perusteella on annettu suosituksia nautojen opettamisesta sähköpaimenaitoihin. 